\title{
THE BEHAVIOR OF THE WELDING CONNECTION MODELS BETWEEN REINFORCING STEEL AND STEEL PLATE
}

\author{
Hery Kristiyanto ${ }^{1,2}$, Andreas Triwiyono ${ }^{2}$, Muslikh² and Ashar Saputra² \\ ${ }^{1}$ Department of Civil Engineering, Faculty of Engineering, Cokroaminoto University Yogyakarta 55161, \\ Indonesia. \\ ${ }^{2}$ Department of Civil and Environmental Engineering, Faculty of Engineering, Gadjah Mada University, \\ Yogyakarta 55281, Indonesia \\ ※Corresponding Author, Received: 06 March 2020, Revised: 07 April 2020, Accepted: 24 April 2020
}

ABSTRACT: The welding connection between reinforcing steel and steel plates are widely used as part of a building structure system, including the precast concrete connection system. This experimental study aimed to investigate the behavior of the tee joint welding between reinforcing steel and steel plates, using both the yield (YS) and tensile (TS) strengths as indicators. It was also directed towards understanding the strain hardening value (TS/YS), which is the ratio between these factors. The experiment was conducted by testing three types of welding connections, WC-1, WC-2, and WC-3, under tensile loads. The WC-1 and WC-2 are common models mostly used to join steel components in reinforced concrete structures, while WC-3 was the proposed connection model. The results showed TS/YS ratios of WC-1, WC-2, and WC-3 specimens were 1.19, 1.23, and 1.27, respectively. This means the value of the proposed specimen is higher than the required 1.25 by the ASTM A706M and was also recorded to have the best tensile strength.

Keywords: Welding connection, Reinforcing steel, Steel Plate, Strain hardening value

\section{INTRODUCTION}

Welding connections between reinforcing steel and steel plates are important components in reinforced concrete structures, including the joint between the reinforcement and the base plate of the column connected to the foundation. The two common types of welded joints are presented in Figures $1 \mathrm{a}$ and $1 \mathrm{~b}$ and are observed to have different welding joints. In Figure 1a, there is no steel plate punching process, and the reinforcing steel was welded to one side of the plate. Meanwhile, in Figure 1b, the steel plate was perforated first, after which the steel reinforcement was inserted in the hole and welded on the two sides.
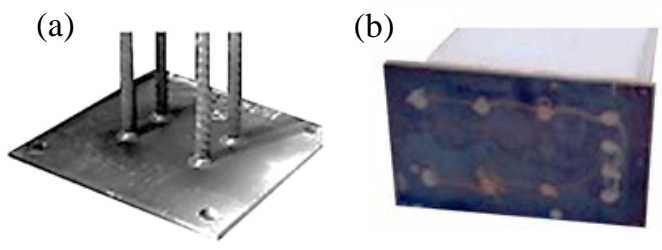

Fig. 1 Welding joints between reinforcing steel and steel plates [1]

Some research has been conducted on reinforced concrete connection through welding of the components, especially reinforcing steel with steel plates. For example, Ersoy and Tankut [2] examined the precast concrete joints system of a beam near the surface of the column. This involved placement of anchor plates on the top and bottom of the beam and the two sections were connected to the vertical reinforcing steel using welding method, as shown in Figure 2.

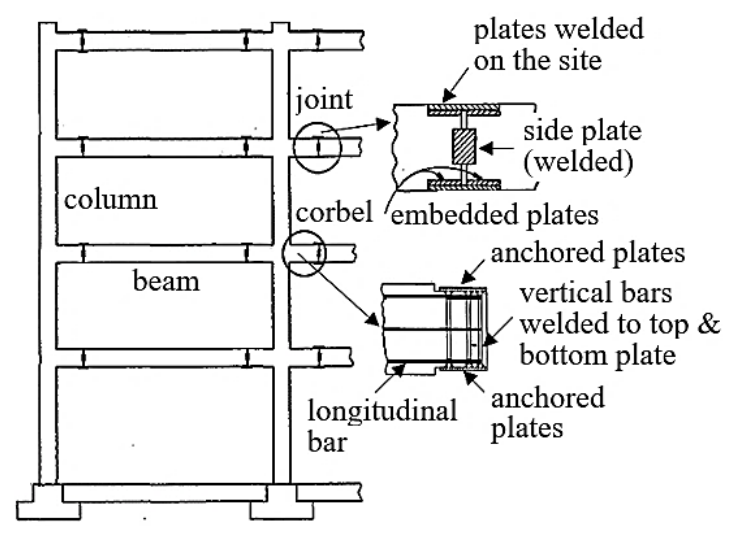

Fig. 2 Precast concrete joints system [2]

In a different research, Bahrami, Madhkhan, Shirmohammadi, and Nazemi [3] tested the precast concrete beam-column joined by welding the bottom reinforcing steel on steel plates connected to the corbel. Meanwhile, Girgin, Misir, and Kahraman [4] examined the cyclic behavior of hybrid beam-column joints with the reinforcing steel of the bottom beam welded on the beam endplate. The results showed the maximum strain in the bending reinforcement of the welded lower beam plays an essential role in the behavior of all parts of the joint. 
Zhong, Xiong, Chen, Deng, Chen, and Zhu [5] tested the precast concrete beam-column with the joints located in the beams close to the column surface. This involved welding each of the bottom reinforcement steel of the two beams on a perforated steel plate, after which they were joined using bolts, as shown in Figure 3.
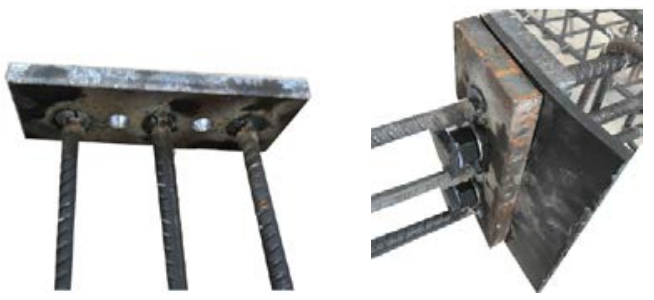

Fig. 3 Connection on the bottom reinforcement steel of the beam [5]

Ding, Xio, Chen, and Khan [6] studied precast concrete joints in the beam section near the column surface by welding the longitudinal reinforcement of the upper and lower parts. Moreover, Xie and Chapman [7] investigated the welded joints on reinforcing steel, and the cross-section of the half connection between steel reinforcement and steel plate due to the annular cavity of the flash welding is shown in Figure 4 (a). The cross-sectional area of the rod was $492 \mathrm{~mm} 2$ while the area connected to withstand the shear force was only approximately $235 \mathrm{~mm} 2$. Therefore, the flash welding stress between the surface of the components was significantly reduced.

Figure 4 (b) shows a cut diagram of the relationship between reinforcing steel and steel plates connected through a CED curved line. The flash welding was shown to be joined to the circular reinforcement between $\mathrm{AC}$ and $\mathrm{BD}$ and, in all the test specimens, the fatigue failure was observed to have started from the basic welding at CD or at the connection of the reinforcement with flash welding indicated in $\mathrm{AB}$.

(a)

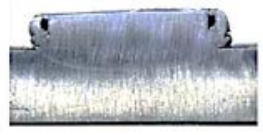

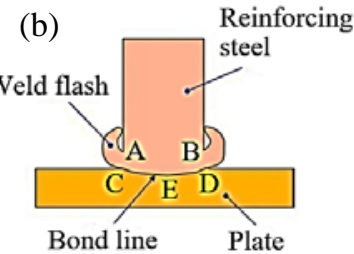

Fig. 4 The cross-section of welded reinforcing steelplate joint [7]

Apostolopoulos, Savvopoulos, and Dimitrov [8] studied the behavior of the lap welded joints on steel reinforcement due to tensile loads. This involved using different reinforcement and weld sizes, and by focusing on the lateral movement of the steel rod ends. The lap welded joint is represented in Figure 5 (a), while Figure 5 (b) shows the invisible element as the part with the tensile load beyond the yielding point of the material, but the welded joint was able to bear the force.
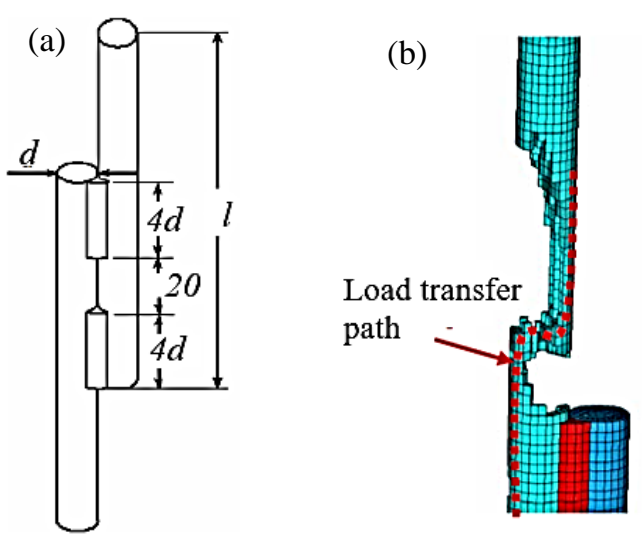

Fig. 5 The lap welded joint [8]

Teguh and Mahlisani [9] showed the results of welding connections between reinforcing steel with varied welding length and with the average yielding strength higher than reinforcing steel. Moreover, Tavio, Anggraini, Raka, and Agustiar [10] examined the TS/YS ratio in steel grades of 420 , 550,650 , and $700 \mathrm{MPa}$ and found grade 420 to have the highest value reaching more than 1.25. Meanwhile, Paulay and Priestley [11] explained each increase in melting strength led to the reduction in the maximum strain and length of the yield plateau, as shown in Figure 6.

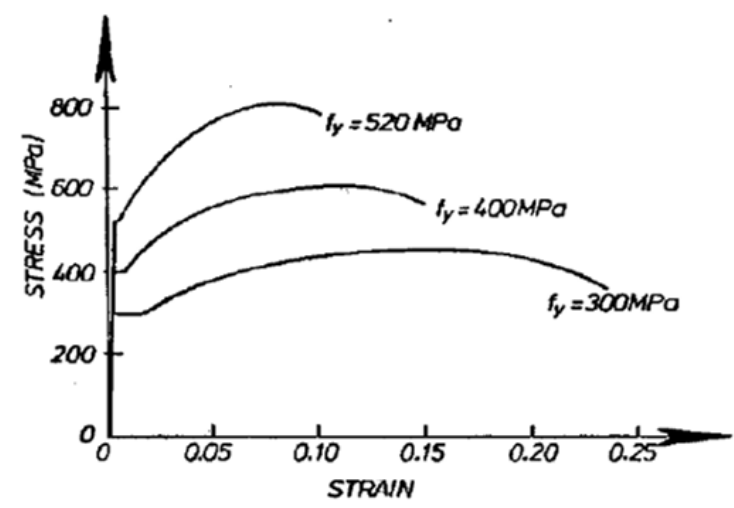

Fig. 6 Typical stress-strain curves for reinforcing steel [11]

The quality of the welded joint in a reinforced concrete structure has been discovered to have effects on the overall structural behavior. Even though it is a standard to conduct separate tests for the yield and tensile strengths of reinforcing steels and plates, it is also very important to evaluate the quality of the welding joints. Therefore, this paper 
tested the tensile and yield strengths of welded joints between reinforcing steel and steel plates and also examined the ratio between these factors (TS/TY) due to its importance to structural ductility.

\section{EXPERIMENTAL}

Three types of connections between reinforcing steel and steel plates were tested at the Department of Civil and Environmental Engineering Universitas Gadjah Mada to determine their behavior under tensile loads. A steel reinforcement with a diameter of $16 \mathrm{~mm}$ and length $40 \mathrm{~cm}$ and a circular steel plate with a diameter of $16.3 \mathrm{~cm}$ and a thickness of $1.9 \mathrm{~cm}$ were used as materials for this experiment. Moreover, the elbow welding was in accordance with the SMAW technique involving the use of E7016 electrodes and $5 \mathrm{~mm}$ welding thickness.

WC-1 (Welding Connections-1) involves welding one side of the steel plate to the steel reinforcement, without punching as shown in Figs 7a and 7d. WC-2 involves punching a hole in the steel plate, after which the steel reinforcement was inserted in the hole and welded on both sides, as shown in Figs 7b and 7e.

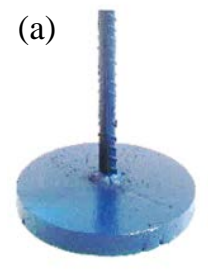

(d)

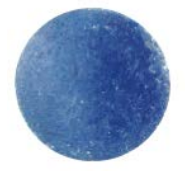

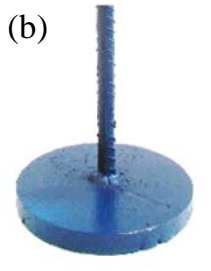

(e)

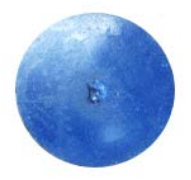

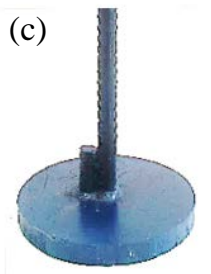

(f)

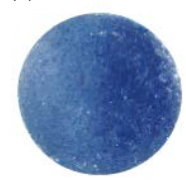

Fig. 7 Three types of test specimens

WC-3 made use of additional reinforcing steel with the same diameter as the primary reinforcement and a length 2.5 times its diameter, and they were both welded to one side of the steel plate without punching, as shown in Figs 7c and 7f.

Three test specimens were made for each of these connections, and laboratory tests were conducted using equipment such as Universal Testing Machine (UTM), load cell, linear variable differential transformers (LVDT), and data logger. The process involved placing the steel plate of the specimen on a steel frame holder connected to load cells with the lower end of the reinforcing steel clamped. The UTM provided the tensile loads with the magnitude measured using the load cell, while the displacement caused by these loads was measured using LVDT and the results recorded from the connected data logger. The whole setup is shown in Figure 8.

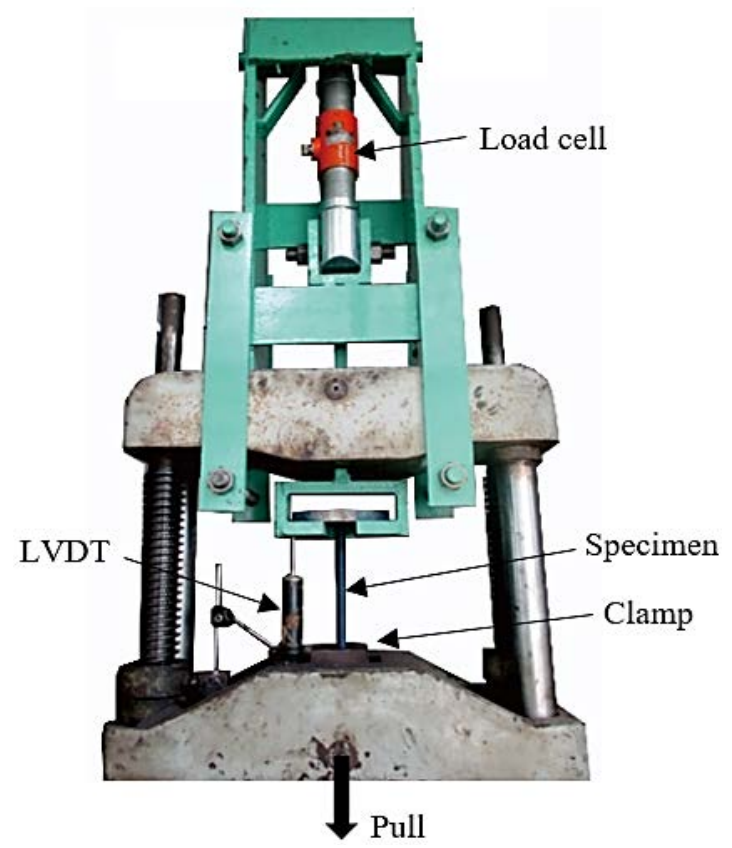

Fig. 8 Testing setup

A similar setup has also been conducted in a pull-out test to study the bond behavior between steel reinforcement and high strength concrete [12].

\section{RESULTS AND DISCUSSION}

\subsection{Material Testing Result}

The welding and steel reinforcement used in the connection model were tested to determine their tensile strength, and the results for the steel reinforcement are presented in Table 1. According to ASTM A706M [13], the criteria for thread longitudinal reinforcement for Grade 420 include a minimum yield strength of $420 \mathrm{MPa}$, maximum yield strength of $540 \mathrm{MPa}$, the tensile strength of at least $550 \mathrm{MPa}$, elongation for diameter 16 should be at least $14 \%$, and tensile strength should not be less than 1.25 times the actual yield strength.

Table 1 The results of the tensile strength test of steel reinforcement

\begin{tabular}{ccccc}
\hline Specimens & $\begin{array}{c}\text { YS } \\
(\mathrm{MPa})\end{array}$ & $\begin{array}{c}\text { TS } \\
(\mathrm{MPa})\end{array}$ & $\begin{array}{c}\text { Elongation } \\
(\%)\end{array}$ & $\begin{array}{c}\text { Ratio } \\
\text { TS/YS }\end{array}$ \\
\hline D16-1 & 450 & 598 & 24 & 1.33 \\
D16-2 & 452 & 599 & 25 & 1.33 \\
D16-3 & 452 & 600 & 24 & 1.33 \\
\hline Average & 451 & 599 & 24 & 1.33 \\
\hline
\end{tabular}

YS = Yield Strength, TS = Tensile Strength 
Table 1 shows the steel reinforcement has an average yield and tensile strengths of $451 \mathrm{MPa}$ and $599 \mathrm{MPa}$, respectively, while Elongation and $\mathrm{TS} / \mathrm{YS}$ ratios were $24 \%$ and 1.33 , respectively. This means all the factors have values higher than the requirements.

The steel plates and welding joints were tested using UTM, and the results are presented in Table 2. The materials were manually welded with a simple electric arc welding technique known as Shielded Metal Arc Welding (SMAW). SP was used to represent the steel plate, while W70 was the welding connection using the E7016 electrode.

Table 2 The tensile test result of the steel plate and the welding joint

\begin{tabular}{ccc}
\hline No & Specimens & TS (MPa) \\
\hline 1 & SP-1 & 443 \\
2 & SP-2 & 437 \\
3 & SP-3 & 427 \\
\hline & Average & 436 \\
\hline 4 & W70-1 & 428 \\
5 & W70-2 & 359 \\
6 & W70-3 & 377 \\
\hline & Average & 388 \\
\hline
\end{tabular}

According to the American Welding Society, AWS A5.1-91, regulations [14] concerning specifications for carbon steel electrodes for shielded metal arc welding, E7016 is classified to have a nominal tensile strength of $70 \mathrm{Ksi}(483 \mathrm{MPa})$.

The results showed the welding tensile strength for the specimens was 428, 359, and $377 \mathrm{MPa}$ or $88.6 \%, 74.3 \%$, and $78.1 \%$ of $483 \mathrm{MPa}$, which is the standard value. The average was recorded to be 388 MPa or $80.33 \%$ in comparison with the standard grade, and this means the welding quality general exceeds $75 \%$, which is the endurance factor required by the Indonesian National Standard specifications for structural steel buildings, SNI 1729:2015 [15].

The welding joint failure of the specimens is presented in Figure 9, and the W70-1 specimen was discovered to have broken in the steel plate while W70-2 and W70-3 broke in the welding section.

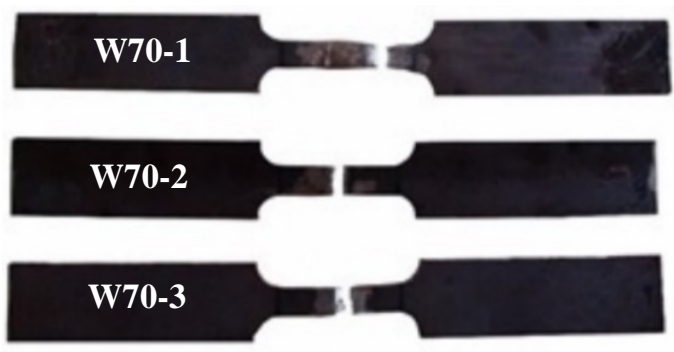

Fig. 9 The failure of the welding joint

This was associated with high tensile strength recorded for W70-1, which allowed its weld joint to be higher than the tensile strength of the steel plate as well as lower values obtained for W70-2 and W70-3, as observed in Table 2.

\subsection{Connection Test Result}

The results of the joint testing between the steel reinforcement and the steel plate, as presented in Table 3, showed the average yield strength of WC1 , WC-2, and WC-3 specimens was 467, 456, and $468 \mathrm{MPa}$, respectively.

Table 3 The results of the joint testing between the reinforcing steel and the steel plate

\begin{tabular}{ccccc}
\hline No & Specimens & $\begin{array}{c}\text { YS } \\
(\mathrm{MPa})\end{array}$ & $\begin{array}{c}\text { TS } \\
(\mathrm{MPa})\end{array}$ & $\begin{array}{c}\text { Ratio } \\
\text { TS / YS }\end{array}$ \\
\hline 1 & WC-1.1 & 464 & 545 & 1.17 \\
2 & WC-1.2 & 472 & 559 & 1.18 \\
3 & WC-1.3 & 466 & 565 & 1.21 \\
\hline & Average & 467 & 556 & 1.19 \\
\hline 4 & WC-2.1 & 435 & 539 & 1.24 \\
5 & WC-2.2 & 466 & 605 & 1.30 \\
6 & WC-2.3 & 468 & 535 & 1.14 \\
\hline & Average & 456 & 560 & 1.23 \\
\hline 7 & WC-3.1 & 463 & 587 & 1.27 \\
8 & WC-3.2 & 467 & 601 & 1.29 \\
9 & WC-3.3 & 473 & 600 & 1.27 \\
\hline & Average & 468 & 596 & 1.27 \\
\hline
\end{tabular}

These values, expect for WC-2.1 with a lower yield, are higher than $451 \mathrm{MPa}$ obtained for the reinforcing steel. Moreover, the average tensile strength for WC-1, WC-2, and WC-3 was 556, 560, and $596 \mathrm{MPa}$, respectively, and these are observed to be lower than $599 \mathrm{MPa}$, obtained for the reinforcing steel. The comparison of the yield and tensile strength values is shown in Figure 10.

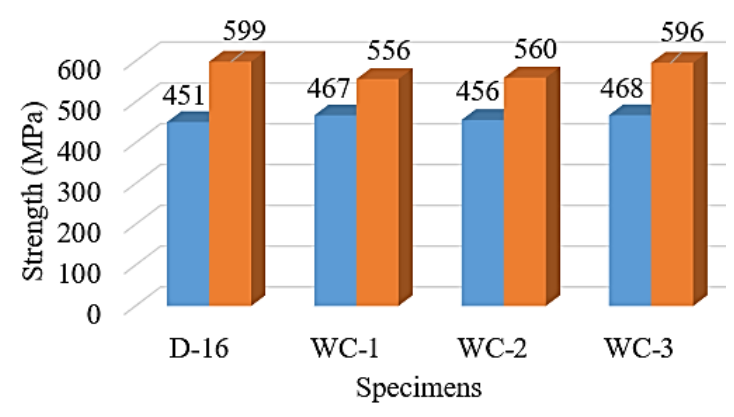

घield Strength $\quad$ Tensile Strength

Fig. 10 The comparison of YS and TS values

The average TS/YS ratio of WC-1, WC-2, and WC-3 specimens was $1.19,1.23$, and 1.27 , respectively, and these were found to be lower than 1.33 obtained for the reinforcing steel. Moreover, 
only WC-3 specimens have a value higher than 1.25 , and this means they have uppermost tensile and yield strength. The ratios are compared in Figure 11.

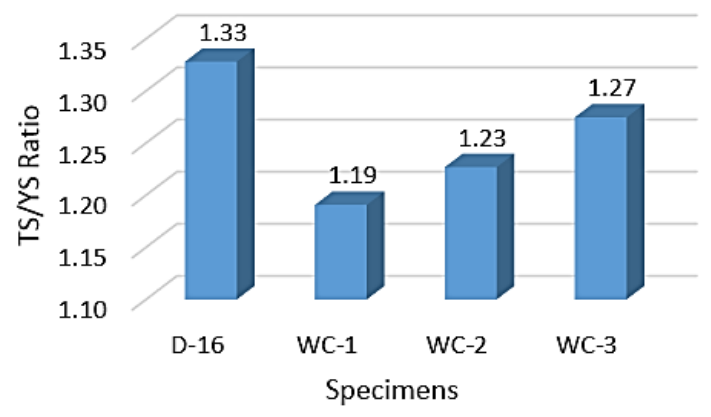

Fig. 11 The comparison of TS/YS ratios

Reinforcing steel has a slightly lower yield strength than WC3-3 specimens, as shown in Figure 12 , but the maximum strain and the yield plateau are longer, and this makes the steel reinforcement more ductile.

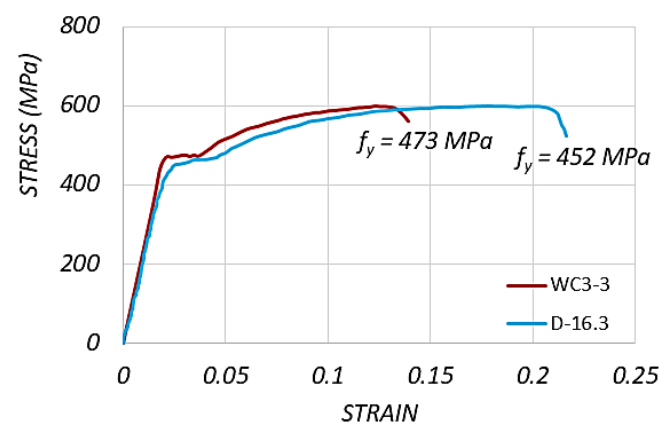

Fig. 12 Stress-strain curves of reinforcing steel and steel plate

It is important to focus on the yield and tensile strength of the reinforcing steel due to their effect on the behavior of the structure during an earthquake load. The TS/YS value ratio, known as strain hardening value, shows the ductility capacity of the part of the structure or component the material is used [16].

A higher TS/YS ratio is better for the structure because it shows a more exceptional energy absorption ability before failure, and ensures a plastic hinge occurs at the desired location. Moreover, a more significant deformation is experienced as a visible warning to the occupants of the building before it collapses.

ASTM A706M and ASTM A615M [17] regulations and many international regulations related to the planning of reinforced concrete in earthquake areas require the TS/YS ratio must not be less than 1.25. The results showed the ratio of WC-3 specimens was 1.27 , while a single reinforcement without welding was 1.33. This, therefore, means the magnitude of the ratio reduced with welding. This is in line with the findings of previous research that welding on reinforcing steel reduces ductility while its effect on the yield strength of the hot-rolled bars was negligible [18].

\subsection{Collapse Pattern}

The collapse pattern of the specimens is shown in Figure 13, and WC-1 sample was observed to have collapsed by releasing the reinforcement from the welded joint and WC-2 by breaking the reinforcing steel connected directly to the welded joint on the plate while the reinforcing steel broke in the middle for one of the specimens. Meanwhile, the WC-3 test collapsed with the reinforcement of two of the samples discovered to have broken right at the end joint while the last failed with the release of the reinforcing steel from the welded joint. The crooked reinforcing steel shows there had been a distribution of forces with eccentricity.
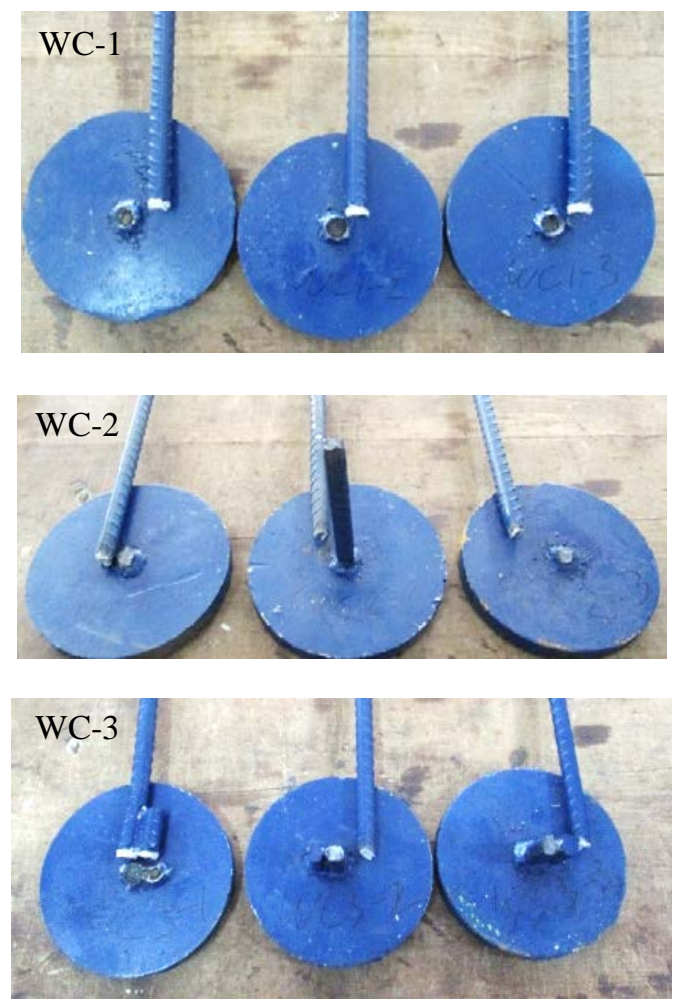

Fig. 13 Collapse Pattern

Figure 13 shows WC-3 has the largest connecting weld area due to the addition of reinforcing steel pieces, while WC-2 is also greater than WC-1 due to additional welding at the bottom of the steel plate.

The tensile strength of the welded joint between the reinforcing steel and the steel plate was observed to be equivalent to the connecting weld area between the materials. This can be seen in the 
results in Table 3, which showed the order of magnitude of tensile strength for WC-3, WC-2, and WC- 1 to be 596, 560, and $556 \mathrm{MPa}$ respectively.

\section{CONCLUSION}

1. This research focused on the importance of ductility associated with the selection of the appropriate connection model. The TS/YS value ratio shows the ductility capacity of the part of the structure or component the material is used. This involved understanding the effect of the minimum TS/YS ratio of 1.25 in preventing premature joint failure due to brittle behavior and strain concentration and ensuring the development of plastic joints in the intended location.

2. The TS/YS ratio for the WC-1, WC-2, and WC3 specimens was $1.19,1.23$, and 1.27 , respectively, and these were observed to be lower than 1.33 recorded for the reinforcing steel. This is consistent with the results of previous studies that welding reduces ductility.

3. The proposed specimen, WC-3, had a TS/YS ratio of 1.27 , which is higher than 1.25 required by the ASTM A706M.

4. The tensile strength of the specimens, WC-1, WC-2, and WC-3 was 556, 560, and $596 \mathrm{MPa}$, respectively, and these were observed to be equivalent to the connecting weld area between reinforcing steel and steel plate. Moreover, WC3 was recorded to have the highest tensile strength value.

\section{ACKNOWLEDGMENTS}

The authors appreciate the Ministry of Research, Technology and Higher Education, and the Ministry of Finance through the Lembaga Pengelolaan Dana Pendidikan (LPDP) for providing funding through the Beasiswa Unggulan Dosen Indonesia-Dalam Negeri (BUDI-DN) for this research.

\section{REFERENCES}

[1] The International Federation for Structural Concrete, Structural Connections for Precast Concrete Building, FIB:2008, Bulletin 43.

[2] Ersoy, U., and Tankut, T., Precast Concrete Members With Welded Plate Connections under Reserved Cyclic Loading, PCI Journal, July-August, 1993, pp.94-100

[3] Bahrami, S., Madhkhan, M., Shirmohammadi, F., and Nazemi, N., Behavior of Two New Moment Resisting Precast Beam to Column Connections Subjected to Lateral Loading. Engineering Structures, 132, 2017, pp.808-821.

[4] Girgin, S.A., Misir, I.S., and Kahraman, S., Experimental Cyclic Behavior of Precast
Hybrid Beam-Column Connections with Welded Components. International Journal of Concrete Structures and Materials, Vol.11, No.2, 2017, pp.229-245.

[5] Zhong, Y., Xiong, F., Chen, J., Deng, A., Chen, W., and Zhu, X., Experimental Study on a Novel Dry Connection for a Precast Concrete Beam-To-Column Joint, Journal Sustainability, 11, 4543, 2019, pp.1-22.

[6] Ding, T., Xiao, J., Chen, E., and Khan, A., Experimental Study of the Seismic Performance of Concrete Beam-Column Frame Joints with DfD Connections, J. Struct. Eng., American Society of Civil Engineers (ASCE), 146(4), 2020, pp.1-16.

[7] Xie, M., and Chapman, J.C., Static and Fatigue Tensile Strength of Friction-Welded Bar-Plate Connections Embedded in Concrete. Journal of Constructional Steel Research, 61, 2005, pp.651-673.

[8] Apostolopoulos, C.A., Savvopoulos, P.T., and Dimitrov, L., Design Problems in Lap Welded Joints of Reinforcing Steel Bars, Scientific Proceedings VIII International Congress "Machines, Technologies, Material”, Year XIX, Vol. 3, 2011, pp.48-54.

[9] Teguh, M., and Mahlisani, N., Experimental Study of Flexural Behavior of Reinforced Concrete Beams with Variety Lap Splice of Reinforcing Steel Bars, Applied Mechanics, and Materials, Vol. 845, 2016, pp.132-139.

[10] Tavio, Anggraini, R., Raka, I.G.P., and Agustiar, Tensile Strength/Yield Strength (TS/YS) Ratios of High-Strength Steel (HSS) Reinforcing Bar, Proceeding of the International Seminar on Metallurgy and Material, 2018, pp.1-8.

[11] Paulay, T., and Priestley M.J.N, Seismic Design Of Reinforced Concrete and Masonry Building, John Willey \& Sons, Inc. The USA, 1992.

[12] Shen, D., Shi, X., Zhang, H., Duan, X., and Jiang, G., Experimental Study of Early-Age Bond Behavior between High Strength Concrete and Steel Bars using a Pull-Out Test, Contruction and Building Material, vol 113, 2016, pp.653-663.

[13] American Society for Testing and Material, ASTM A706/A706M: 2016, Standard Specification for Low-Alloy Steel Deformed and Plain Bars for Concrete Reinforcement, USA: ASTM International.

[14] American Welding Society, AWS D1.1/ D1.1M:2004, Structural Welding Code- Steel: AWS.

[15] National Standardization Agency, SNI 1729: 2015, Specifications for Structural Steel Building (in Indonesian). 
[16] Djavanroodi, F. And Salman, A., Variability of Mechanical Properties and Weight for Reinforcing Bar Produced in Saudi Arabia, International Conference on Materials Sciences and Nanomaterials, 2017, pp.1-6.

[17] American Society for Testing and Material, ASTM A 615/A 615M: 2016, Standard Specification for Deformed and Plain CarbonSteel Bars for Concrete Reinforcement, USA: ASTM International.
[18] Moustafa, T., Khalifa, W., El-Koussy, M.R., El-Reheem, N.A., Optimizing the Welding Parameters of Reinforcing Steel Bars, Arabian Journal for Science and Engineering, Vol 41, 2016, pp.1699-1711.

Copyright (C Int. J. of GEOMATE. All rights reserved, including the making of copies unless permission is obtained from the copyright proprietors. 